\title{
電子工業の発展と真空技術 ${ }^{*}$
}

\author{
納 賀 勤 一**
}

\section{1. 序言}

電子一業と真空技術の関連を全面的に採り上げるの は，余りにも範費が広すぎて手に負えない，真空蒸着や スパッターによる薄膜形成技術，荷電粒子ビームによる 加工技術, 観测・分析胢の真空利用機器, 更には低䕌音 化のための冷却䉼熱等まで含めると, 電子工業のあらゆ る分野に直接，閔接，真空技術は利用されていると言っ てよかろう。一方, 其空装㯰自体にもマイクロコンピュ ーターをはじめ冬種 IC や個別電子部品が計測, 制御に ふんだんに使われている時代である。私はかつて電子放 射カソードの研究に往事していたのでここでは私に割 合馿染みの深い電子管および半導体と真空技術の関連に 話を絞らせて頂きたい。もっとも，近代の電子工業の目 思張るばかりの発展は、この二つの能動素子の発展が なければ有り得なかったことだし，これらと真空技術と の関連は，大筋としては電子工業と真空技術との関連を 代表するだろうと想っている。ただ，私が研究の実務を 離れてからすでに20年に近く，最近の状況，特に真空技 術の進歩には全くらとくなっているし，記憶も大分薄れ ている、そんなわけで，思い違いや大きな欠落もあるこ とと思うが，御寞容願いたい。

\section{2. 歴史的展望}

電球の帆余分の電極を一つ封人して電圧を加える と，白熱したフィラメントとその電極との間に電流が流 れるといら T.A. Edison の発見 (Edison 効果) が1883 年, J.A. Fleming による二極管の発明が1904年，L. de Forestによる三極简の発明が1907年だから，電子工業と 真空技術との付命いは大約80年の歴史を持っていると言 ってよい，最近の20简閒は半筫体の進歩が華々しく，電 子管はその陵にかくれた感があるが，それ以前は電子管 が電子工業の主役を演じていたこと洞知の事実であ る，電子管の大部分が真空管であることから分るよう に，真空技術との関係は文字通り直接的であり，真空技

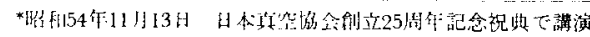

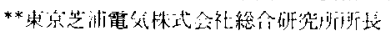

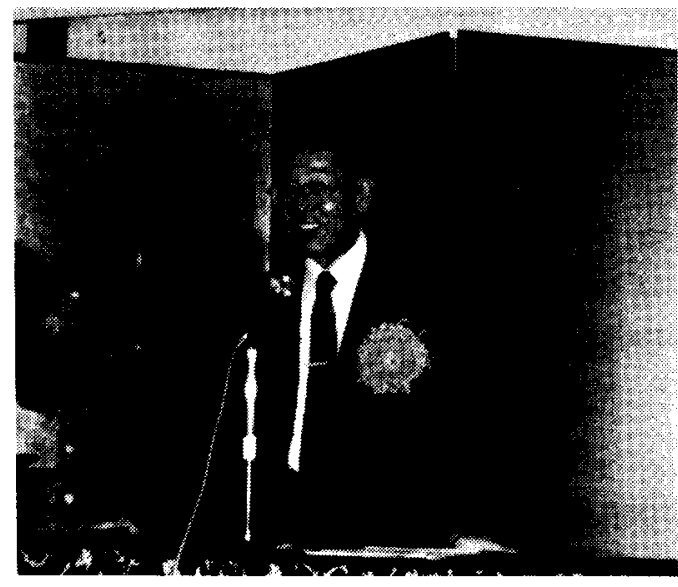

講演する著者

術の進歩が電子管の発展をむたらし, 電子管性能の高度 化への要求が真空技術の進紧を促して，相互にからみ合 って発展を遂げて来た。

ところで, Edison 効果が電球で発見されたことが象徵 するよらに，この期閒に捛ける電子管と真空技術の関係 を述べるには，電球・真空技術・電子管の連熬を無視す ることはできない，そして，ここに巨大な起跡を残した のが I. Langmuir である，1907年，GE 社の研究所に入 社した Langmuir が最初にとり上げたのがタングステン 電球の改良に関する研究であり，電球内の真空度を改善 することがそのポイントであると考えた時点が, 後にノ 一ベル賞受賞につながる彼の業績の岖発点であった，彼 の研究は一方では，ガラス，金属部品，真空コックの潤 滑剂等からのガス放出の解明を経て, 排気技術の進歩, 能率の高い真空ポンプの開発へと進んで行った. る5一 方では，真空中の残留ガスが高温のタングステン・フィ ラメントの寿命に及ぼす影響に関する研究となり，高温 のタングステン・フィラメント上での水素分子の解離現 象，水の分子がタングステン原子をガラス管壁に運んで 電球の黒化を来たす水サイクル現象等の発見を通して, 表面化学といら学問分野を形成した.この延長線上で単 分子（原子）膜の概念を生み，タングステン上の水素, 
酸素, トリウム, セシウム, 等の吸着層に関する実験に 基づいて，有名な Langmuir の吸着等温式を導き出し， 吸着の物理学を確立した。この外にも彼の業績には熱電 子放射の証明，空間電荷の発見等があるが，吸着と熱電 子放射の変化との関係から吸着に伴なら仕事関数の変化 を明らかにし，実用的なトリエーテッド・タングステン カソードの熱電子放射機構の解明にも貢献している.

以上の如く, Langmuir の研究は電球から出発したと はいえ, 真空技術, 表面化学, 吸着の物理, 熱電子放射 を基盤として，電子管の発展に抜群の貢献をしたと言っ てよい.

話は元に戻るが，今なおブラウン管はテレビジョンや 各種ディスプレー装置に，マグネトロンはレーダー装置 や電子レンジに龙大な市場を有し，産業電子工業，民生 電子工業の中で不動の位置を占めているばかりでなく， 1980年代とはいえども，その役割は簡単には他のものに 置き換るとは思えない. しかし，現在，受信管を代表例 として電子管のかなりの部分はその役割を半導体素子に 譲っている．だが，電子管時代に培われた真空技術は半 導体工業でも又, 重要な役割を果している. もちろん, その関係は電子管の場合ほど直接的ではないが，研究， 生産の両面から生じた新たな要求は, さらに新しい真空 技術の進歩を促して, 再び相互扶助の形の発展が行われ ている，その最大の理由は，半導体素子が固体素子であ るとはいえ，その特性は単結晶母体の性質のみならず結 晶表面の性質によって大きく左右されるからであり，さ らに現在のメモリー素子の大半を占める MOS 構造に至 っては, 表面の電気伝導特性が母体のそれと違っている こと自体を利用しているからである。このことについて は後でもら少し詳しく述べるが，上記のような歴史から 見て，真空技術はまさに電子工業の重要な共通基盤技術 の一つと言ってよいだろら。

いささか余談になるが，トランジスターを発明したベ ル研究所の有名な三人男は，いずれも1930年代に電子放 射に関係の深い研究を行っている，J. Bardeen が仕事 関数について，W. Shockley が表面準位について理論的 な研究を行っていたことは良く知られているが, Shockley はその外に，ガラス管の内面に電極用の導電体と蛍 光体を塗布し, 軸に沿ってタングステン等のフィラメン トを張った Shockley tube (図 1 参照) と称する管球を 作り，フィラメント表面における仕事関数の分布や，吸 着原子の表面扡散の観察を行っている。管壁に塗布した 電極に高電圧を印加し，フィラメントから放出される熱 電子を半径方向に直進させれば，軸方向には抬大はない が，円周方向には管球とフィラメントの半径比だけ拡大 されるといら簡単な熱電子顕微鏡である. 又, W.Brattain

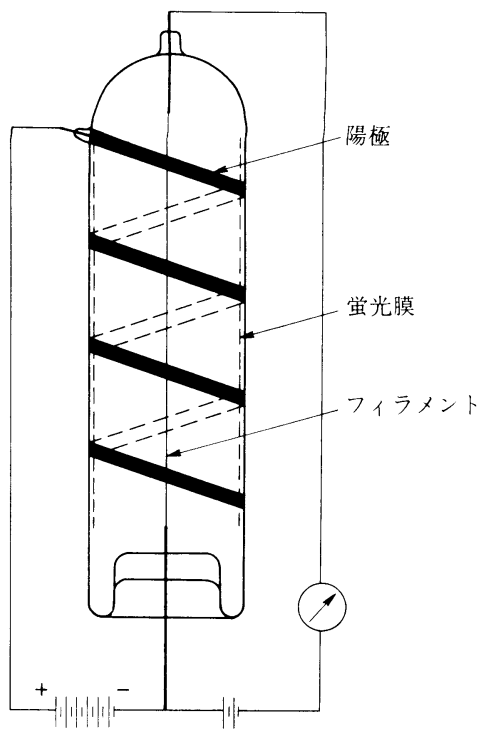

図 1 Shockley tube の概念図

は吸着に伴なう仕事関数の変化について，主として実験 的な研究を行っている. 彼等が電子放射に関連して始め た表面研究の研究歴が，後でトランジスターの発明に大 きな役割を果しているように思えてならない，強いて言 えば，真空技術は表面の研究を媒介として，電子管と半 導体を結びっける宿命を持っていたといらことになる。

表 1 に真空技術, 電子管, 半導体における主な出来事 を，戦後を主体として年表に表わしてみた。この表は主 として日刊工業真空技術講座の年表から抜き出したもの に若干気付いたものを追加して作ったのだが, 資料が古 いのと私の不勉強のために, 最近の進歩が抜けている.

又, 表の中で電子管, 半導体の項目は, おおよその工業 化された年代を示している.

この表で分るように，真空技術の進歩は昭和20年代か ら30年代前半にかけて集中しており, 又, 電子管の新工 業製品としての出現も, 略々同時代に集っている. しか し，この真空技術の進歩は主として半導体側からの挑戦 によるものであり, 一方, 電子管の進歩は戦 後のラジ オ，テレビの普及に伴なら受信機，放送機からの要請や 通信機, 航空電波機器等の需要扡大に由来するもので, 両者の間には直接の因果関係はないように思う。ただ当 時の記憶では，電子管の寿命や信頼性が，真空技術に関 する考え方の進歩の恩恵を受けていたことは確かであ る。 
表 1 真空技術年代表

\begin{tabular}{|c|c|c|c|}
\hline 年 代 & 子 & 空 & 半導体素子 \\
\hline 戦前 & $\begin{array}{ccc}\text { 受 } & \text { 信 } & \text { 管 } \\
\text { 送 } & \text { 信 } & \text { 管 } \\
\text { 工業用ブラウン管 } \\
\text { X } & \text { 線 } & \text { 管 } \\
\text { 放 } & \text { 電 } & \text { 管 } \\
\text { 光 } & \text { 電 } & \text { 管 } \\
& & \text { 等 }\end{array}$ & $\begin{array}{l}\text { H. G. McLeod: マクラウド真空計の発明 (1874) } \\
\text { M. Pirani: ピラニ真空計 (1906) } \\
\text { W. VonVoege: 熱電対真空計 (1906) } \\
\text { W. Gaede: ベーン形油回転ポンプ (1909) } \\
\text { R. Pohl, P. Pringsheim: 真空蒸着法 (1912) } \\
\text { W. Gaede: 水銀拡散ポンプ (1915) } \\
\text { O. E. Buckley: 電離真空計 (1916) } \\
\text { C. R. Burch: 油払散ポンプ (1928) } \\
\text { 硬質ガラス用封着金属フェルニコの実用 (1934) } \\
\text { K. C. D. Hickman: 分溜式油拡散ポンプの特許 (1935) } \\
\text { W. B. Nottingham: } 1 \times 10^{-8} \text { Torr 測定 (1937) } \\
\text { ヘリウム・リークディテクター（1939 1945?） }\end{array}$ & 鉱石検波器 \\
\hline $1950-$ & $\begin{array}{c}\text { 光 電 子増 倍管 } \\
\mathrm{T} \text { V 用白黒ブラウン管 } \\
\text { 進 行 波 管 } \\
\text { 反射形クライストロン }\end{array}$ & $\begin{array}{l}\text { J. R. O. Downing: } \alpha \text { 線真空計 (1946) } \\
\text { C. M. Fogel: フォーゲル形真空計 (1946) } \\
\text { D. Alpert: 超高真空測定 (1948) } \\
\text { A. E. Cameron, D. F. Eggers Jr: タイムオブフライト形質量 } \\
\text { W. H. Bennett: 高周波形質量分析計 (1950) } \\
\text { R. T. Bayard, D. Alpert: B-A ゲージ (1950) } \\
\text { H. Sommer, H. A. Thomas, J. A. Hippel: オメガトロン (1951) } \\
\text { A. H. Beck, A. D. Brisbane: マグネトロン真空計 (1952) } \\
\text { P. A. Readhead: トパトロン（1952) } \\
\text { W. Paul, H. Steinwedel: マスフィルタ（1953) }\end{array}$ & \\
\hline $\begin{array}{c}1955- \\
(\text { 昭30) }\end{array}$ & $\begin{array}{l}\text { マグネトロン（レーダ } \\
\text { 用） }\end{array}$ & $\begin{array}{l}\text { Heraeus 社：メカニカルブースタ }(1955) \\
\text { L. D. Hall: スパッタイオンポンプ (1958) } \\
\text { W. Becker: ターボモレキュラーポンプ (1958) }\end{array}$ & $\begin{array}{l}\text { トランジスタ } \\
\text { (点接触形) }\end{array}$ \\
\hline 1960 & \begin{tabular}{|} 
イメージオルシコン \\
$\mathrm{T}$ V 用カラーブラウン
\end{tabular} & $\begin{array}{l}\text { B. N. Baily, R. L. Chuan: クライオポンプ (1959) } \\
\text { R. L. Jepsen: クライオソープションポンプ (1959) } \\
\text { M. A. Biondi: 吸着トラップ (1959) }\end{array}$ & (接合形) \\
\hline & $\begin{array}{c}\text { ビ ジ コン } \\
\mathrm{UHF} \text { クライストロン } \\
\text { X線蛍光増倍管 }\end{array}$ & $\begin{array}{l}\text { P. A. Readhead: レッドヘッド真空計（1960) } \\
\text { W. R. Wheeler, M. Carlson: コンフラットシール (1961) } \\
\text { B. Kindl: バルクゲッタポンプ (1963) }\end{array}$ & $\begin{array}{l}\left(\begin{array}{l}\text { プレーナ } \\
\text { ー形 }\end{array}\right) \\
\text { (MOS 形) }\end{array}$ \\
\hline $\begin{array}{c}1965- \\
(\text { 昭40) }\end{array}$ & ガスレーザ管 & $\begin{aligned} \text { A. S. Nazarov: チタンサブリメーションポンプ } & (1965) \\
& \text { イオン注入技術 } \rightarrow\end{aligned}$ & I G \\
\hline $1970-$ & 蛍光表示管 & $\begin{array}{r}\text { J. R. Arther: 分子線エピタキシー } \\
\text { プラズズマエッチング技術 } \rightarrow\end{array}$ & LSI \\
\hline $\begin{array}{c}1975- \\
(\text { 昭50) }\end{array}$ & & & \\
\hline $1980-$ & & & 超 LSI \\
\hline
\end{tabular}




\section{3. 電子管と真空技術}

電子管の動作原理は，電子の流れを格子電極に与える 電圧やその他の色々の手段で制御することである，真空 管の場合，電子の流れの場は真空であるが，そこでの真 空の程度が電子の流れに影響を与えることは，電子管製 造初期の頃は別として，現実にはほとんど起らない，真 空度が $10^{-5}$ Torr の析の時の電子の平均自由行程が数 $\mathrm{m}$ であるのに対し，真空管の電極間の距離は，特殊な場合 を除けば, 数 $\mathrm{mm}$ ないし数 $\mathrm{cm}$ だからである. 真空と の関係で基本的に問題となるのはカソードの性能であ る.

カソードと言っても熱電子放射カソード，光電子放射 カソード等種々あるが, 最も広く用いられている熱電子 放射カソードを例にとって考えよう．熱電子放射カソー ドにも, 純タングステン線, トリエーテッド・タングス テン線, 酸化物陰極, インプレグネート・カソード等が あるが，いずれにせよ電子放射は表面現象だから吸着に よって起る仕事関数の変化海感である. 表面に衝突し た気体分子又は原子が総べて吸着し，かつ，離脱しない と仮定すると，単分子（原子）層を形成するのに必要な 時間は $10^{-6}$ Torr の桁の真空度で大体数秒程 度, $10^{-10}$ Torr の桁でも数時間程度である。ところが, 仕事関数は 単分子（原子）層の $10 \%$ 位の吸着があってもかなり大き な変化を示すから，吸着確率が 1 でないことを考虑に入 れても，数千ないし数万時間の安定動作を保証するには $10^{-10}$ Torr よりはるかに高度の超高真空が必要なことに なる.

実際の真空管の管内真空度は動作条件や寿命の初期か 末期か等によって異るが， $10^{-6} \sim 10^{-7}$ Torr位である. 量 産技術的にはこれ位の真空度が実現可能な限界であろ 5.それにもかかわらず実際の真空管で数千ないし数万 時間の寿命が得られているのは, 熱電子放射カソードが 高温に加熱されているために残留ガスの吸着を防ぐこと

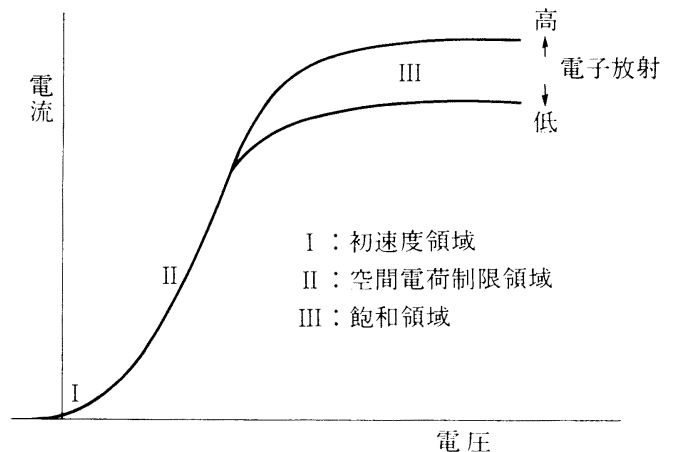

図 2 二極管特性
が出来ることと*, 空間電荷制限領域（図 2 参照）で動作 しているために若干の電子放射の変動は空間電荷で遮蔽 されて特性に影響を及ぼさないことによるものである。 図 2 には二極管特性を示してあるが，本質的には多極管 でも変らない。

カソードが高温に加熱されているということは，上記 のように真空管にとって本質的な長所をもたらすと同時 に, カソード物質の蒸発によって寿命の限界が定められ るといら。これも又本質的な短所にも連がっている。こ の寿命問題を逃れたいといらことが，トランジスターの ような固体増幅器を開発したいという駆動力の一つにな っていたのだから運命は皮肉である.

話は元に戻るが，それでもなおかつ，量産品の真空管

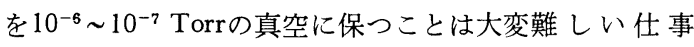
で，真空管の歴史を通して真空は最大の問題であった。 ガラス管球，電極金属，セラミック部品等からのガス放 出はどうすれば減らすことが出来るか，封じ切り後の放 出ガスを吸収するにはどんなゲッターを如何に使うべき か等の問題は, 材料, 部品の前処理プロセス, 排気プロ セス, 排気装置等の面から，真空に関する物理 ・化学的 理解と, それに基づく技術的対策の進歩を刺激した。 こ の進歩は又，排気技術のみならず，材料の選択まで含め た広義の電子管設計へも還元され，電子管は次第に高性 能, 高信頼度となり, 又, 設計の自由度を増して高周 波, 高出力へと発展し, 更に特殊用途の複雑な構造を可 能にした.

今の話の最後の部分をもう少し具体的に述べよう，真 空管時代に数の上で大勢を制したのは受信管である，最 盛期には当社だけでも月産 700 万個を超えていたと記憶 している。こうなると, 自動排気装置のインデックス は，よくこれで排気できるものだと思うほど早くなる． 短時間で必要な真空度を得るということが焦点であり， その解決のための苦労を通して龙大な知識の集積が行わ れた。 それから導き出されたノーハウとして一番印象に 残っているのは, ガラス管球, 電極, その他の部品共に 封じ切りまで冷えている所がなく, 脱ガス工程, 酸化物 カソードの分解 (炭酸塩から酸化物へ), 排気管の熔断等 で放出されるガスが吸着して管内に残存する所をなくし ておくことがコッであったことである.ブラウン管は容 積, 管球内面積ともに受信管に較べると圧倒的に大きい が，それに比例した大きなゲッタ一面積をとることが出 来ず，しかも高電圧で使用するためにカソードがスパッ

\footnotetext{
*吸着分子 (原子) に上る表面の被覆度を $\theta$, 管内圧力を $P$, 吸着エネルキ 一を $E$, カソード温度を $T\left({ }^{\circ} \mathrm{K}\right)$ とすると

$\theta \infty P \cdot \exp (E / k T)$

ただし，k汭ルッマン定数
} 
ターされる可能性もあるし, カソードに要求される電流 密度も大きいといら具合で, 真空に関する条件は受信管 よりはるかに厳しい，ただ幸いにも本当の量産が始まっ たのはテレビの放送が開始された時だから, 受信管につ いて既に蓄積されていた真空技術の知識を充分に活用す ることが出来た. 各種のマイクロ波管, 撮像管について も同様な事情があった。

話はやや脇道に外れるが, カソード屋としての当時の 思い出話を少し述べさせて頂く. 真空管の特性不良, 短 寿命等のトラブルの大部分が，カソードの電子放射の劣 化に起因している。 そのために, トラブルが起る度にカ ソード屋が吊し上げられた。 しかし，その原因を追及し てみると, 又大部分が真空度劣化ないしは有害ガス源 (主として水)の管内持込みに由来していた。 この場 合, カソードは一種のスケープ・ゴート（身代り，いけ にえ）であって，カソードの罪だけを追及してみても， もち万ん問題怯解決しない，私は反論のために，“カソ 一ド心臟説”を編み出さざるを得なかった，つまり“人 間の死は心臓の停止によって認定されるが，だからと言 って死因の総べてが心臟病だというのは暴論ではない か. 癌や結核や高血圧等の治療こそ本筋である.”とい う論拠である. 日頃お世話になっていた真空技術に対し ては誠に申し訳ない次第だが，死因の大部分は真空病で あった。

先にスケープ・ゴートといら言葉を使ったが，スケー プ・ゴートは原始社会ばかりでなく, 最も近代的, 合理 的社会であるはずの技術の社会でも時々現れる。電子管 の場合, 酸化物カソードのベースメタルとアルカリ土金 属酸化物コーティングとの間に出来るインターフェース 化合物層が，一時その立場に立たされたことがある。電 子管をパルス動作させる時のパルス波形の乱れのよう に, 周波数特性を劣化させるのは確かにインターフェー ス化合物の高抵抗層の存在のせいだが，一時は酸化物力 ソードのあらゆる劣化現象の元凶のように言われた。 も ちろん，一つの仮説としてインターフェース化合物層を 用いて現象の物理モデルを考えるのは結構なことで，仮 説の真偽を確認してから次の段階に進むのなら，これは 正常な進め方で，スケープ・ゴートとは言わない，その 過程を拔かして，その時代のムードに流されて魔女裁判 的に犯人に仕立てるのがスケープ・ゴートで，結局はと んでもない損失を起すことになる，自然相手だから，や がては事実に導かれて正しい道に戻るのだが，技術の場 合，特に量産品の製造技術の場合には，時間と金の莫大 な無駄使いを惹き起すことになる。

さて，こうして電子管は現在の絢爛たる電子工業の発 展の基礎を築いて来た. 又, この間に得られた真空技術
に関する知識の内, 真空部品の加熱による脱ガスの重要 性, ゲッターの効能と限界等に関する知見や, ポンプ油 の逆拡散, 液体窒素トラップにおける吸着と脱着, 電離 真空計におけるクリーンアップ作用の経験は, 次の超高 真空技術開発における基盤として役立った. D. Alpert 等の超高真空実現のための排気プロセスには, これらの 知識, 経験がふんだんに活用されているのが見らけられ る.

\section{4. 半導体と真空技術}

1948年に生れたトランジスターから現在の LSI, 超 LSI に至る半導体素子は, 電子管の役割を肩代りしたと いらだけでなく, 電子管では出来なかった多くの新しい 発展を生み出し, 電子工業の花を咲かせた。電子計算 機, マイクロコンピューター, 実用衛星等々による情報 化社会の発足と普及は電子管では不可能だったであろ 5 .

半導体素子と真空技術の関係を分類してみると，

(1) 表面研究のための超高真空技術

（2）製造ライン用の真空蒸着，スパッター，イオン注 入, 電子ビーム露光, CVD (Chemical Vapor Deposition), ドライエッチング等の各種装置

(3) 精密観察・分析装置としての SEM, XMA, ESCA 等

である。(3)は汎用とは言え, 極微量不純物に敏感であ り, また微細加工を必要とする半導体分野では, 他の分 野に㧍けるより一段と重宝して使われている。(2)は真空 度もさることながら, クリーン・バキウムでかつ量産に 適するといら課題を真空技術に投げかけた。 もち万ん電 子管の場合でも, 全圧だけでなく中味の成分ガスの種類 やその分圧, 又, ポンプ油蒸気等の炭化水素の有無は問 題であったが，微量不純物の影響，表面の污染の影響を 受け易い半導体では一段と神経質である。それにして も, 真空技術との関係で特筆すべきものは，表面研究の ために要求された超高真空技術であろう.

半導体に扔ける電気的特性と表面との関係はトランジ スターにおいて急速にクローズアップされたが，実はト ランジスター発明以前に, 固体幅堌器といら考えに基づ く実験段階ですでに指摘されている，例えば，Shockley は図 3 に示寸ように, 一枚の石英板の片面に半導体膜, 他の面に金の薄膜を着けてコンデンサーを形成し，電圧 を印加すれば， $\mathrm{Q}=\mathrm{C} \cdot \mathrm{V}$ に従って誘起される電荷によ って半導体膜の電気伝導度が変化するだろらという予想 のもとに害験を行った. 半導体膜には図に示すように電 気伝導度測定のための電極が着けてある. しかし，観測 された電流の変化は予測の10\%にも満たないものだっ 


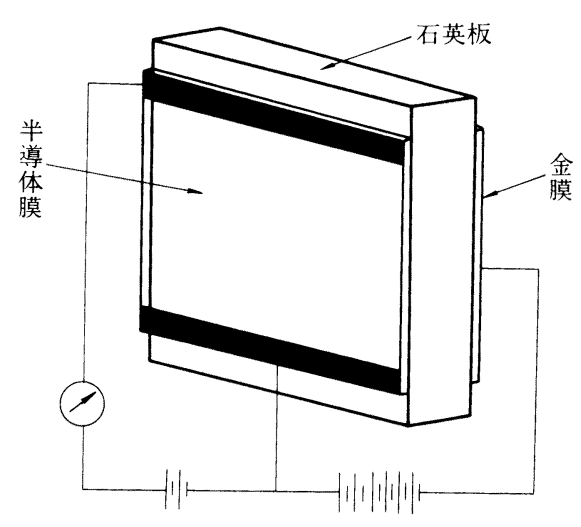

図 3 Shockley の実験概念図

た.この実験結果の解釈のために，Bardeen は半導体表 面に関する物理的研究の必要性を指摘している.

もら一つの代表的な実験は, Benzer の行ったゲルマニ ウム単結晶の接触点における整流特性に関するものであ る. それ以前は, 結晶検波器の整流特性は金属針と半導 体結晶との接触点におけるエネルギー障壁が引き起すも ので, 雑に言うと整流特性曲線はエネルギー障壁の高さ によって定まり，障壁の高さは針金属の仕事関数と半導 体の仕事関数の差に等しいと考えられていた. Benzer は 一個のゲルマニウム結晶から二個の試料を切り出し, 図 ‘の(a)に示すように接触させて電流・電圧特性を測定し た.この場合，接触片は同一物質だから等しい仕事関数 を持っており，従来の考え方によればエネルギー障壁は 形成されず, 電流・電圧特性は直線的になるはずであっ た.ところが，結果は予想に反して図 4 の(b)に示すよう な非直線特性が得られた。この実験結果の解釈も半導体 表面についての研究の進歩に待たなければならなかっ た.

さて, トランジスターが開発された後, 初期において は特性に関する理論と実験との食い違い，不安定性，雑 音等の問題が続出し，その解釈のために半導体表面にお ける電子準位の存在, その電子準位に基づく電子, 正孔 の発生や再結合等の概念を生み，半導体表面研究の必要 性を一層刺激した。この研究の一派が原子的に見てきれ いな表面について研究を進めた清浄表面派であり，表 1 に示した超高真空排気装置や排気プロセス，超高真空 計，また，フラッシング法，イオン衝撃アニール法，憵 開法等の清浄表面作成技術など高度の真空技術開発の駆 動力になったわけである，先にも述べたが，表 1 におい て昭和20年代から30年代前半にかけて, 超高真空技術の 進歩が集中的に出現しているのはこのためである。表に は出ていないが，メタルバルブ等の部品やFEM, FIM, LEED 等の表面観察技術が急速に進歩したのもこの時期

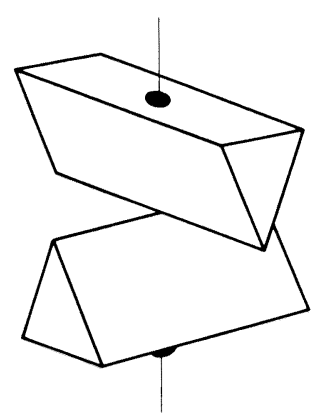

(a) 試料

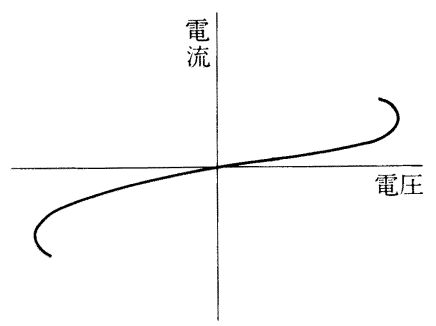

(b) 測定結果

図 4 Benzer の実験

であり，真空機器協会の設立も丁度この時期である。

これら清浄表面派の仕事は他の一派, つまり, 実際表 面派からは，酸化膜で覆われたり，あるいは弗酸等によ るエッチングで生じたスティン膜を着けた污れに表面を 持つ現実の半導体素子における表面現象の理解には役立 たないという批判を受けた．直接に役立つか否かという 点ではこの批判は当を得ていると私も思らが，清浄表面 派の業績が表面科学と超高真空技術の進歩に大役を果し たのは事実であり，それらを通して間接的には現実の半 導体素子の進歩にも貢献したと感じている.

上記のように表面の科学の土台に乗って開花したトラ ンジスターは, その後の諸々の障碍を二度, 三度表面の 科学との二人三脚の許に解決し, シリコンが素材として ゲルマニウムに取って替るに及んで表面酸化膜を巧妙に 利用してプレーナートランジスターを生み，これがバイ ポーラ IC への道を開いた，一方では，もっと直接に表 面現象を利用したものとして， $\mathrm{n}$ 形基板結晶の表面に生 ずる $\mathrm{p}$ 形反転層を利用した MOS 形電界効果トランジス ターを生み(上記の $\mathrm{n}$ 形, $\mathrm{p}$ 形は逆の場合も同じ), 電気 特性の安定化に散々苦労したあげく，さらに MOS·IC へと発展して行った．素材がゲルマニウムからシリコン に代ったということは，その後の進歩，特に IC の進歩 にとって決定的に重要なことであるが，その最大の理由 は，表面酸化膜がシリコンの場合はゲルマニウムの場合 に較べて，はるかに安定だということである。

現在，バイポーラ IC は民生用リニア IC および論理 
用ディジタル IC の花形であり，MOS·IC はメモリー 用ディジタル IC の主役であって, これらが今日のマイ クロエレクトロニクス時代を築いているのは周知のこと であろう。

\section{5. 今後の展望}

不勉強を顧みずに今後の予測を述べるのは甚だ僣越だ とは思らが, 強いて言えば, 電子工業の分野で1980年代 に大きな飛躍が期待されるのは, やはりマイクロエレク トロニクスとオプトエレクトロニクスであろう．もっと も, 電子計算機による画像処理, 言語処理のようにソフ トウェア主導形のものやシステム的なものは, 真空技術 との縁が余り深くなさそうだから除外しての話である.

ここでも又一般論を述べるのは難しいので, 超 LSIを例 にとって考えてみよう.

ダイナミック・ランダムアクセス・メモリー (d-RA

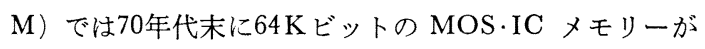
頭を出し始めた．今までのように IC の集積密度が 2 年 で4倍になるという経験則が何時までも続くとは思われ ないが，80年代末には 1 メガビットのメモリーが製品と して出始め, 開発段階では 4 メガビットが対象になるこ ともあながち夢とは言えない. 1 メガビット・メモリー のIC パターンのデザインルール（最小線幅および線間 間隔）はすでにサブミクロンの範囲だろうから，4メガ ビットともなれば 0.5 ミクロンを下回るだろう。これの 実現には当然多くの技術的困難が予想されるが, 微細加 工技術はその最たるものである，IC パターンのマスク 製作は電子ビーム露光装置を用いざるを得ない．現在の 電子ビーム露光装置ではカソードとしてタングステン線 または六弗化嗍素の熱電子カソードが用いられている.

この装置で 0.5 ミクロン以下の微細加工ができるように 電子ビーム径を細くすることは, 不可能ではないが実用 性からは遠くなりそらに思われる.

さらに微細加工をするためにはカソードの輝度を上げ る必要がある.三種のカソードの輝度を表 2 に示した が，六弗化嗍素の熱電子カソードより更に輝度を上げる とすると, 先ず考えられるのはタングステン針状カソー ドからの電場電子放射である，電場電子放射カソードは
表 2 電子ビーム露光装置用カソードの輝度

\begin{tabular}{l|l|c}
\hline \hline \multicolumn{2}{c|}{ カソードの種類 } & 輝度 $\left(\frac{\mathrm{A}}{\mathrm{cm}^{2}, \mathrm{str}}\right)$ \\
\hline \multirow{2}{*}{ 熱電子放射 } & $\mathrm{W}$ (ヘアピン形) & $1 \times 10^{5}$ \\
\cline { 2 - 3 } & $\mathrm{LaB}_{6}$ & $5 \times 10^{6}$ \\
\hline 電場電子放射 & $\mathrm{W}$ (針形) & $\sim 10^{8}$ \\
\hline
\end{tabular}

$\mathrm{A}:$ アペ゚ str.: ステラディアン

SEM ではすでに実用化されている例もあり,電子ビーム 露光装置でも開発試作が行われているが, 電子ビーム露 光装置で稼動率の高い実用機を作るときに先ず問題とな るのは超高真空技術であろう。

先に電子管の項で, $10^{-6} \sim 10^{-7}$ Torrの真空度で真空管 が安定に動作しているのは, 熱電子放射カソードと空間 電荷制限領域のおかげであると述べたが，電場電子放射 カソードの場合はいずれの恩恵を蒙ることも出来ない. 吸着分子を除去するために, 針状カソードを時々高温加 熱するとしても, やはり10-11 Torr の桁ないしはそれ以 上の高真空が必要であろう。研究用装置や観測用機器で はなく，稼動率の高いことを要求される製造ラインの装 置として，これだけ高度の真空というのは整しい条件で ある。

超 LSI 以外の例として, マテリアル・デザイン, つま り理論的に期待される特性を持つ材料の設計に関する研 究も80年代に進歩が望まれる. 現状では未だ初期段階で あるが, IBMの研究所の江崎氏が行っている分子線エピ タキシーによる超格子結晶の作製はその例である. 電子 材料として必要な純度を得るには, 超高真空が必要にな る. 江崎氏の装置のバックグランドの真空度は10-11 Torr の桁と聞いている.この方法が新材料供給に実用化され る時には, 又々, 真空技術に厳しい挍願いをすることに なろう。

“自然は真空を嫌ら”といら言葉があったが，電子工 業が真空技術に対して，嫌われても嫌われてもプロポー ズするといら状況は今後も続きそうである。 その反面, こうして発展した電子工業の成果が真空技術に貢献する ことも，期待できるのではなかろうか. 